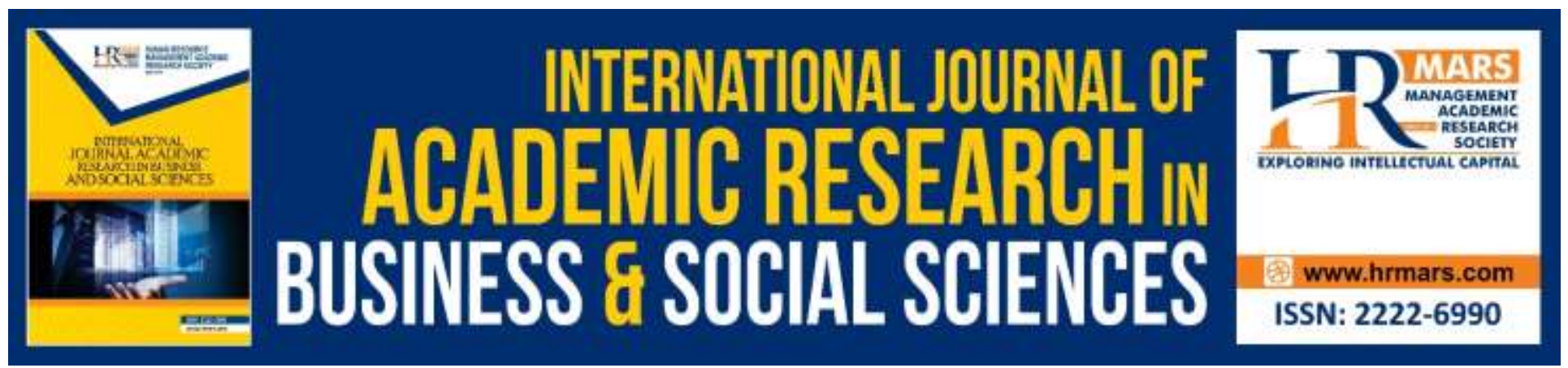

\title{
Competency in Career Management among Technical University Students
}

Normah Zakaria, Norhasyimah Hamzah, Noor Azlin Yamin, Nur Izeanty Hamidon, Arihasnida Ariffin, Siti Nur Kamariah Rubani

To Link this Article: http://dx.doi.org/10.6007/IJARBSS/v9-i13/6253 DOI: $10.6007 /$ IJARBSS/v9-i13/6253

Received: 22 March 2019, Revised: 17 May 2019, Accepted: 02 June 2019

Published Online: 19 August 2019

In-Text Citation: (Zakaria et al., 2019)

To Cite this Article: Zakaria, N., Hamzah, N., Yamin, N. A., Hamidon, N. I., Ariffin, A., \& Rubani, S. N. K. (2019). Competency in Career Management among Technical University Students. International Journal of Academic Research in Business and Social Sciences, 9(13), 173-182.

Copyright: (C) 2019 The Author(s)

Published by Human Resource Management Academic Research Society (www.hrmars.com)

This article is published under the Creative Commons Attribution (CC BY 4.0) license. Anyone may reproduce, distribute, translate and create derivative works of this article (for both commercial and non-commercial purposes), subject to full attribution to the original publication and authors. The full terms of this license may be seen

at: http://creativecommons.org/licences/by/4.0/legalcode

Special Issue: Revolutionizing Education: Challenges, Innovation, Collaboration, 2019, Pg. 173 - 182 http://hrmars.com/index.php/pages/detail/IJARBSS

JOURNAL HOMEPAGE

Full Terms \& Conditions of access and use can be found at http://hrmars.com/index.php/pages/detail/publication-ethics 


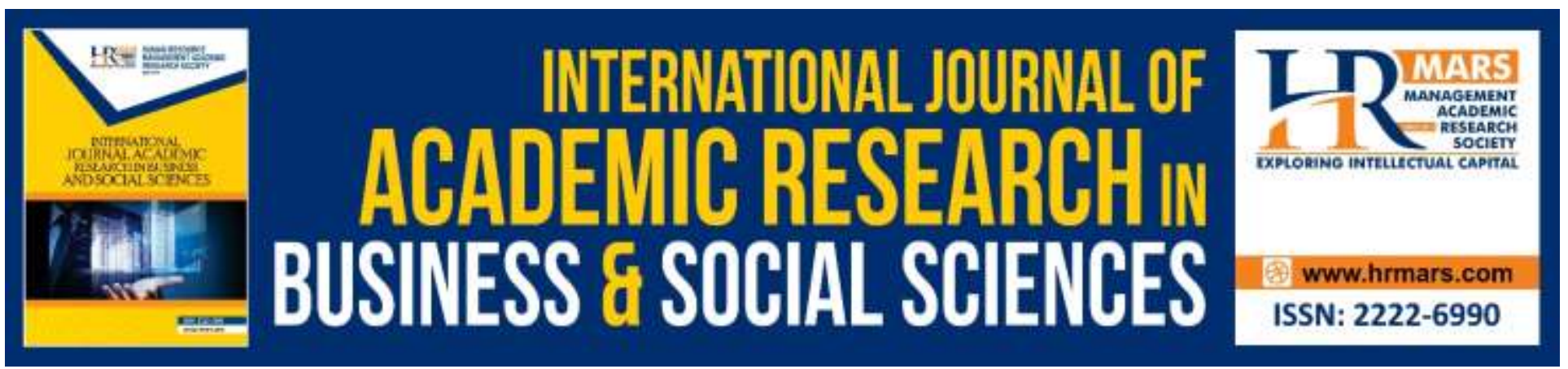

\title{
Competency in Career Management among Technical University Students
}

\author{
Normah Zakaria, Norhasyimah Hamzah, Noor Azlin Yamin,Nur \\ Izeanty Hamidon, Arihasnida Ariffin, Siti Nur Kamariah Rubani \\ Universiti Tun Hussein Malaysia, Malaysia
}

\begin{abstract}
Challenge to place themselves in jobs, require graduate that have high competency in career management to compete and fulfill the human resource demand. Thus, this research is to find the differences of the technical student in their career management competency between courses field and university. Samples are final year students from University of Tun Hussein Onn Malaysia (UTHM) and University of Technical Malaysia (UTeM), with sample size (n) are 581. A questionnaire was used as the instruments to measure the career management competency among students. The data were analyzed using independent t-test and One Way ANOVA to answer the research questions. Research findings revealed there is a significant difference in career management competency between students' courses field, $p<.05$ and university, $p<.05$, with mean difference value $=0.13$. The implication of this study can give a positive picture to the student how to manage their career own then the right path.
\end{abstract}

Keywords: Competency, Career management, Technical University, Students

\section{Introduction}

Rapid changes of globalization have made labor needs advanced as one of the main agendas of the country towards the country's development through the vision and mission of the country namely 'Wawasan 2020' in achieving better standards of developed countries by 2020. Thus, to reach the level of developed countries, several things need to be taken by specific pillar attention which is the first one, the addition of labor in fields related to engineering and Polytechnic and the second edition of the educational institutions of engineering and Polytechnic (Mclntosh, 2008).

The transformation of education is in line with a national higher education strategic plan in transforming education and training towards the production of human capital that has a first-class mentality and to meet market needs. Ministry of Education (MOE) has developed the national higher education strategic plan (NHESP) with seven core which is expanding access and increasing equity, improve the quality of teaching and learning, empowering institutions of higher learning, towards strengthening research and innovation, strengthen the delivery system of $\mathrm{MOE}$, empowering 
institutions of higher learning, intensify an internationalization and cultivate the lifelong learning (Beckton, 2009).

The large allocation has been given to public education institutions for upgrading and finances the programs development potential capable and skilled graduates to serve in the job. According to a report released by the Country's Economic Action Council, five factors lead to difficult engineering graduates to put themselves in the job market. The factors are, difficult graduates find employment that is less skilful and no work experience, the field of study which do not meet the requirements of the industry, limited communications capabilities, especially in English, lack of awareness of the existence of various job vacancies as well as negative attitudes towards graduates' jobs selected (Rusmin, 2010). Therefore, the objective of this research as a below:

1. Is there a significant difference in career management competency between students from two selected universities?

2. Is there a significant difference in career management competency between the students from the seven selected courses?

Although there are thousands of job options, the selection process is complicated. There are many reasons for the difficulty in selecting the individual's career interests in diverse fields; it is unable to assess his / her ability and personality well and lacks the knowledge and information regarding the career to be chosen (Rasul et al., 2009).

\section{Career Management Competency}

Skills in managing a career require every individual to be able to change quickly according to current needs, focus on self-quality, creative and always responsive to his or her duties. Individuals who know how to manage his career will be more confident in the new work environment (Redekopp, Hache \& Jarvis 2009). Because the industry environment now has become complicated, especially the impact of changes in technology and the economy, able to manage the career can up the level of worker confident. Jobs now require the variety of an ability, skill, and knowledge that indirectly gives the implications at the individual as graduates of the university.

According to the statistics of UTHM's engineering graduates, found that the number of graduates with jobs was moderate only 750 students from 1336 UTHM engineering graduates (CARE UTHM, 2013). Meanwhile, according to the statistics of UTEM graduates who have worked there are 899 people from 1523 UTEM students graduating (PJIM UTEM, 2013). The factor of this unemployment is not solely due to a lack of employment but is due to the mismatch between skills required by the labor market with the skills possessed by graduates. This issue means that the mastery of this element requires research on the student itself. The unemployment showed there is a lack of proper management of careers. Students are still unable to plan the desired job according to the suitability of the students. Besides, the level of non-technical skills such as employability skills, soft skills and others among university students is less effective in engineering, especially graduates whereas various forms of skills such as basic skills, self-adaptation, self-esteem, interpersonal skills, communication skills, problem solving skills, thinking skills and technological skills have been applied to students while they are studying at universities (Esa, 2010). Therefore, based on the findings of previous studies, there is a lack of competence in managing a career among engineering graduates. 
Skills in managing self-care require every individual and student, in particular, to be able to change quickly according to current needs, focus on self-quality, creative and always responsive to the task given. Competence is the ability or ability of someone to do the work with the best results. Competence is the characteristic of a person who involves knowledge, behavior, and attitudes that can exhibit brilliant work (Zakaria, 2006). Competence comes from the word 'competency' which means 'to be suitable.' Most previous researchers argue that competence is the ability to perform tasks related to the activities required. The competence concept translated into this study is the competence of managing a career among students who will be involved in the work world. Individuals who are good at managing their career will be more confident in a new working environment (Redekop, Hache \& Jarvis, 2009). Career competence is one of the most important skills to apply in today's education. According to Becker (2003), competence is vital in helping workers to work effectively in the workplace. The application of interpersonal competence applied by the university can provide students with the ability to enter the job market. According to Kamsah (2006), engineering graduates today are still less competent in the aspect of soft skills even though they are competent in technical and technical aspects.

\section{Model of Career Management Competency}

Career management is the capability to develop a career, to intentionally manage the interaction of work, learning and other aspects of the individual's life (Haines, Scott, \& Lincoln, 2003; Watts, 1998; Webster, Wooden, \& Marks, 2004). A model by Ruth Bridgstock is proposing which skills are essential for the development of graduate employability and suggesting how career management plays an integral part. Bridgstock (2009) claimed in his research that career management, competency was the central pillar to develop and keep the nation economically. The career management models had fixed by two variables (independent variables). Self-management skill and career development skill will affect individual disciplinary skill and generic skill (see Figure 1). Career management encompasses career planning by identifying goals and career paths and career development by enhancing knowledge, skills, and competencies. Smith et al. (2009) emphasize continuing career management with individuals developing through self-awareness cycle and careerrelated issues. Therefore, career management competencies supplementary detailed planning of professional development (Watts, 2006), with self-reflection becomes vital in career development.

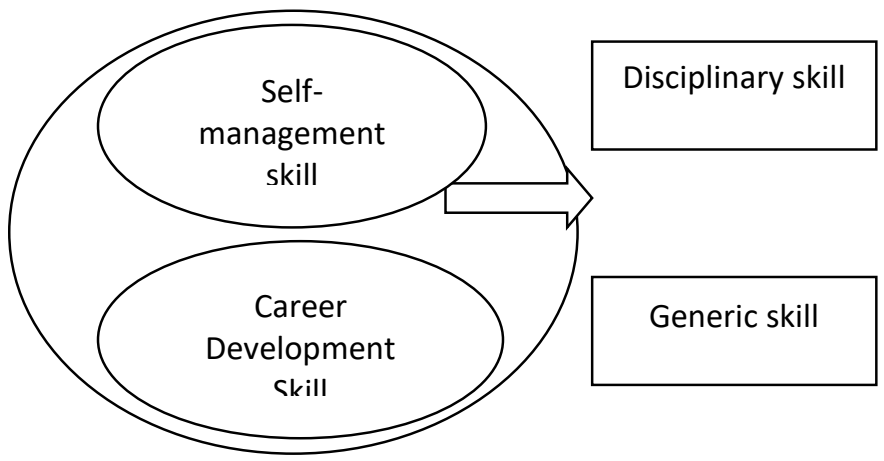

Figure 1: Career Management Competency Model (Bridgstock, 2009) 


\section{Discipline-Specific Skills}

These are the skills usually included in the university curriculum to address specific occupational requirements. These skills originate in specific domains, disciplines or subject matter areas. For instance, an engineering graduate should have the ability to apply principles to engineering practice in order to design and produce experiments. A graduate in engineering should possess the ability to apply appropriate techniques in engineering fields.

\section{Generic Skills}

According to Bridgstock (2009), generic skills are transferable skills and also well-known as 'employability skills' in university. They include such skills as information literacy, working with technology, written and verbal communication, working in teams and numeracy. Overtoom (2000) define the employability skills are transferable core skill group that signify essential functional and enabling knowledge, skills, and attitudes required by the $21^{\text {st }}$-century workplace. They are essential for career success at all levels of employment and all levels of education.

\section{Self-Management Skills}

This skill is related to individual self-quality in terms of value, ability, interest, and goals. Eby, Butts, and Lockwood (2003) revealed that students with strong concepts in career goals and positive attitudes to succeed in their careers showed that they had higher levels of employability than other students.

\section{Career Development Skills}

According to Bridgstock (2009), career development skills are the skills to explore careers, industry and the world of work, securing and maintaining work, as well as exploiting career opportunities to gain improvement or other desired outcomes. Career building skills include; being familiar with the career industry, being able to effectively identify and choose the best opportunities, knowing how long to stay in a role, know how to find and use existing opportunities for career development, knowing how to effectively apply for and obtain work; representing one's skills and abilities in a way that is attractive to employers or clients, and creating social network by creating strategic personal and professional relationships with those who might provide opportunities and essential resources.

\section{Methodology}

This study uses a quantitative approach by using survey method to answer the question of the study. The purpose of this study was to involve the views and perceptions of respondents about the career management competencies to identify the difference career management competency based on the course fields and among the final year of Engineering Technical University students. The survey method was chosen to explore the issues of career management competency. Descriptive statistics such as min and statistical inferential such as independent t-test and one-way ANOVA was used to analyze and explain the issues of study.

\section{Population and Sample}

The population for this study was a final year student for seven courses in engineering at University Technical Malaysia (UTEM) and University Tun Hussein Onn Malaysia (UTHM) as the table 
below. Determination of sample size for this study based on the calculation proposed by (Bartlett, Kotrlik, \& Higgins, 2001) using Cochran formula (Cochran, 1977). Based on the calculation of sample size, the numbers of students required as the sample were a total of 581 people.

Table 1. Courses engineering at UTHM and UTEM.

\begin{tabular}{cc}
\hline University & Course Fields \\
\hline UTHM & $\begin{array}{c}\text { Faculty of Mechanical and Manufacturing } \\
\text { Engineering (FKMP) } \\
\text { Faculty of Electrical and Electronic } \\
\text { Engineering (FKEE) } \\
\text { Faculty of Civil and Environmental } \\
\text { Engineering (FKAAS) }\end{array}$ \\
UTEM & $\begin{array}{c}\text { Faculty of Electrical Engineering (FKE) } \\
\text { Faculty of Electrical and Computer } \\
\text { Engineering (FKEKK) }\end{array}$ \\
& Faculty of Manufacturing Engineering (FKP) \\
Faculty of Mechanical Engineering (FKM)
\end{tabular}

\section{Research Instrument}

A questionnaire was carried out among 581 students as a respondent. The rationale of the selection of this sample because they are final year engineering students in meeting the demands, needs, and wishes of the study to be carried out. All the respondents are final year students and ages almost the same who have gone through learning at the university for at least four years and were full skills managing career by lecturers.

\section{Data Analysis}

Data analysis uses descriptive and inferential analysis. In this study, a descriptive analysis was used to describe information such as a university, courses, a selection of courses followed and aspirations respondents. The inferential analysis used independent t-test and one way ANOVA. The data obtained through this study were analyzed using the Statistical Package for Social Sciences (SPSS) version 20.0. Table 2 shows the total distribution of 581 students by the university. Table 3 shows the mean score of career management competency based on seven-course fields namely FKMP, FKEE, FKAAS, FKE, FKEKK, FKP, and FKM.

Table 2. Distribution of students based on respondents.

\begin{tabular}{cc}
\hline Respondents & Frequency $(\mathrm{N})$ \\
\hline UTHM & 298 \\
UTEM & 283 \\
\hline Total & 581 \\
\hline
\end{tabular}


Table 3. Mean score of career management competency by course field

\begin{tabular}{cc}
\hline Course Fields & Mean Score \\
\hline FKMP & 4.11 \\
FKEE & 4.19 \\
FKAAS & 4.08 \\
FKE & 4.02 \\
FKEKK & 3.94 \\
FKP & 3.94 \\
FKM & 3.92 \\
\hline
\end{tabular}

Table 4, indicate the results of data analysis for the difference between the university. Results of data analysis showed there is a significant difference in statistic between UTHM and UTEM in career management competency with the value, $p=.041, p<.05$ despite differences between mean were small, with the difference mean value, $t=.013$.

Table 4. Independent t-test based on university

\begin{tabular}{cccc}
\hline University & $\begin{array}{c}\text { Mean } \\
\text { Score }\end{array}$ & Sig.Value & $\begin{array}{c}\text { Mean } \\
\text { Difference }\end{array}$ \\
\hline UTHM & 4.12 & & \\
UTEM & 3.99 & .01 & .013 \\
\hline
\end{tabular}

Table 5 shows the results of data analysis showed the existence of a significant difference in statistic based on the specialization that is between FKEE with FKEKK, $p=.038, p<.05$ and FKEE with FKP, $p=.040, p<.05$. While other areas showed no significant difference.

Table 5. Post-Hoc Tukey HSD Test

\begin{tabular}{|c|c|c|c|}
\hline \multirow{4}{*}{ FKEE } & $\begin{array}{c}\text { Course } \\
\text { Fields }\end{array}$ & Sig. Value & \\
\hline & $\begin{array}{c}\text { FKM } \\
\text { FKAAS } \\
\text { FKE }\end{array}$ & $\begin{array}{l}.920 \\
.697 \\
.205 \\
\end{array}$ & $\begin{array}{l}\text { No significant } \\
\text { difference }\end{array}$ \\
\hline & $\begin{array}{l}\text { FKEKK } \\
\text { FKP }\end{array}$ & $\begin{array}{l}.038 \\
.040\end{array}$ & $\begin{array}{c}\text { There is a significant } \\
\text { difference }\end{array}$ \\
\hline & FKM & .160 & $\begin{array}{l}\text { No significant } \\
\text { difference }\end{array}$ \\
\hline
\end{tabular}

\section{Findings and Discussion}

Discussions involve differentiation of career management competencies based on specialization fields and universities amongst final engineering students at UTHM and UTEM.

The Difference in Career Management Competency Based on Course Fields among Final Year Students of Engineering Technical University

Research findings showed that there is a significant difference between the career management competency by course fields. Outcome studies show there is a difference between the 
students of the Faculty of electrical engineering and electronics (FKEE, UTHM) and the Faculty of electronic engineering (FKEKK, UTeM) and the Faculty of manufacturing engineering (FKP, UTeM). The study by Agarwala (2008), which states that the selection of the fields has a relationship and influence the competency of the individual career. Students career management competency depends on the selection area of specialization students; this is because each area of specialization taken by students is given the application of the same to the skills of managing a career but differentiated according to areas of specialization. For example, each specialization has a compulsory subject that must be taken by different students to pass as the subject of entrepreneurship and soft skills.

\section{The Difference in Career Management Competency Based On Universities among Final Year Students of Engineering Technical University}

Research findings showed there is a difference between the competence of managing careers with UTHM and UTeM. The findings are consistent with the results of the study conducted by Ronald et al., (2005) which states that the performance of a university is always measured based on the competence of its students. While both universities show a high level of competence in managing their students, the difference between the two universities remains. The difference is because, every university has a different mission, vision, and goals. The study by McNamara, C. (2007) also notes that, in the realm of reality, no specific model was used in the strategic planning of a higher education institution and it varies according to the requirements and requirements of the university itself. This outcome in line with the results of a study conducted by (Rahim, 2010) that the performance of a university is always measured based on the competencies of the students. Although both universities show the level of competency to manage their career was high among students, differences between the two universities remain.

\section{Conclusion}

This research was conducted based on the need to review the career management competency among technical university engineering students. The need to review the career management competency by identifying the differences based on career fields and universities among final year students of Engineering Technical University due to the lack of research in the relevant field. Also, there are statistics issued by CARE (UTHM), and PJIM (UTeM) stated that employability skill among engineering graduates just moderate. Every year there will be an increase in graduates who have completed their studies. Each graduate who ended their studies not all promised jobs and got a secure job. Most of the graduates had to find their career opportunities to get the job that fits their field during their study at the University. In order to obtain a good job, they had to compete with other graduates have the same academic excellence. On the other hand, for those who lack in career management competency, they have difficulties in finding career opportunities because of the lack of self-efficiency to survive like everyone else. Therefore, the importance of skills in managing his career as an added value which allows a person the individual selected to get secure jobs and fits with their skills.

Conclusions from this study indicate student's career management is also in line with the expectations of researchers who will be more likely to manage a career in the same field as the course being followed. Based on the experience of researchers itself, although a student venture into the 
field of study that is not their interest, the students will do their best to receive and love their field of study. Due to the interest and love of the course can be nurtured through a variety of ways, including the role of the lecturer can attract students to continue their studies. Once interest has been cultivated, it will make students planning to venture into the field more profoundly, and this will make them choose to work in the same field. The researcher found that over $80 \%$ of students were more likely to work in the same field as the courses being followed. These finding can be used by the university to help students learn more about a career that will be their future undertakings.

\section{Acknowledgments}

The authors would like to thank University Tun Hussein Onn Malaysia (UTHM) for funding this research under the contract research grant PPG-V022. The authors would also like to express their appreciation to the Research Centre, UTHM for providing the facilities to perform this research.

\section{References}

Agarwala, T. (2008). Factors influencing career choice of management students in India. Career Development International, 13(4), 362-376. https://doi.org/10.1108/13620430810880844

Bartlett, J. E., Kotrlik, J. W., \& Higgins, C. C. (2001). Organizational research: Determining appropriate sample size in survey research. Information Technology, Learning, and Performance Journal, 19(1), 43-50. https://doi.org/10.1109/LPT.2009.2020494

Beckton, J. (2009). Educational Development Units: The Challenge of Quality Enhancement in a Changing Environment. In B. Les, N. Mike, \& S. Howard (Eds.), The Future of Higher Education Policy, Pedagogy and the Student Experience (1st Editio, p. 186). Great Britain: Continuum International Publishing Group.

Bridgstock, R. (2009). The graduate attributes we have overlooked: enhancing graduate employability through career management skills. Higher Education Research \& Development, 28(1), 31-44. https://doi.org/10.1080/07294360802444347

Caplow, T. (1954). The sociology of Work. Minneapolis, MN, US: University of Minnesota Press.

Cochran, W. G. (1977). Sampling Techniques Third Edition. (John Wiley \& Sons, Ed.) (Third Edition). New York.

Eby, L., Butts, M., \& Lockwood, A. (2003). Predictors of success in the era of the boundaryless career. Journal of Organizational Behavior, 24(6), 689-708.

Haines, K., Scott, K., \& Lincoln, R. (2003). Australian blueprint for career development: Draft prototype.

Mclntosh, S. (2008). Education and Employment in OECD Countries.

McNamara, C. (2007). Field Guide to Nonprofit Strategic Planning and Facilitation. Aunthencity Consulting, LLC.

Rahim, A. R. (2010). Minat Kerjaya, Efikasi Kendiri Keputusan Kerjaya, Kemahiran Employabiliti, Dan Pilihan Kerjaya Pelajar Vokasional Pertanian Di Semenanjung Malaysia. Universiti Putra Malaysia.

Rasul, M. S., Ismail, Y., Ismail, N., Rajuddin, M. R., Amnah, R., \& Rauf, A. (2009). Peranan Institusi Pendidikan Teknikal Dalam Pemupukan Kemahiran 'Employability' Pelajar. Jurnal Teknologi, 50(Jun), 113-127.

Salleh, M. A. (2010). Pendidikan Kerjaya dan Pembangunan Modal Insan (Ist). Bangi: Penerbit 
INTERNATIONAL JOURNAL OF ACADEMIC RESEARCH IN BUSINESS AND SOCIAL SCIENCES

Vol. 9, No. 13, Special Issue: Revolutionizing Education: Challenges, Innovation, Collaboration., 2019, E-ISSN: 2222-6990 ๑ 2019 HRMARS

Universiti Kebangsaan Malaysia.

Smith, M., S. Brooks, A. Lichtenberg, P. Mcllveen, P. Torjul, and Tyler, J. (2009). Career development learning: maximizing the contribution of WIL to the student experience. University of Wollongong, Careers Central, Academic Services Division: ALTC.

Watts, A. G. (2006). Career development learning and employability. 